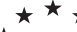

$\star$ Polityki Europejskie.

$\star$ Finanse i Marketing

$\star \star \star 16(65) 2016$

Lucyna Witek

Politechnika Rzeszowska

Katarzyna Szalonka

Uniwersytet Wrockawski

\title{
Alergie pokarmowe i ich wpływ na rozwój rynku żywności funkcjonalnej i ekologicznej
}

\section{FOOD ALLERGIES AND THEIR IMPACT ON THE DEVELOPMENT OF THE MARKET OF FUNCTIONAL AND ORGANIC FOOD}

\begin{abstract}
Postęp cywilizacyjny $w$ dziedzinie higieny oraz zanieczyszczenia środowiska spowodowaty nasilenie chorób alergicznych, (zwłaszcza wśród dzieci), co powoduje, że liczba alergików jest duża i stale rośnie. Jest to choroba uciqżliwa, która obniża wydolność zawodowa $i$ wptywa negatywnie na wydolność edukacyjnq. Te specyficzne potrzeby konsumentów powoduja wzrost zapotrzebowania na żywność ekologiczna i funkcjonalna, a zwłaszcza produkty gdzie catkowicie wyeliminowano alergeny, powodujace dolegliwości. Badania wskazuja, że zarówno żywność ekologiczna jak i funkcjonalna może zapobiegać lub tagodzić skutki alergii pokarmowej.
\end{abstract}

Słowa kluczowe: dysfunkcje pokarmowe, alergia pokarmowa, żywność funkcjonalna, żywność ekologiczna, konsument, zdrowie

\section{Wstęp}

Na rynku pojawiło się wiele produktów spożywczych, gdzie nacisk jest skierowany na walory smakowe i obniżenie kosztów produkcji, co powoduje wykorzystanie dodatków chemicznych takich jak barwniki, polepszacze smaku czy konserwanty. Z kolei produkty z rolnictwa konwencjonalnego posiadają dużą ilość pestycydów, hormonów i antybiotyków. Nie tylko substancje chemiczne dodawane do żywności, ale żywność modyfikowana genetycznie oraz ogólne zanieczyszczenie środowiska stanowią potencjalne źródła alergenów. Choroby alergiczne stanowią poważny problem, którego częstotliwość wzrasta z postępem cywilizacyjnym. Nie tylko w krajach wysoko rozwiniętych rośnie liczba dzieci cierpiących na alergię, ale również w krajach afrykańskich i azjatyckich.

Alergia pokarmowa jest jedną z odmian alergii, która istotnie wpływa na jakość życia ludzi, zwłaszcza dzieci, których liczba $\mathrm{z}$ tym rodzajem alergii wzrasta. Alergia powoduje, że człowiek jest narażony na kontakt z bodźcami (w normalnych warunkach nieszkodliwymi), które organizm odczytuje jako potencjalne zagrożenie i na skutek funkcji obronnych wywołuje niepożądane reakcje, uruchamiając procesy eliminacji, co prowadzi do różnego rodzaju zaburzeń a w skrajnych przypadkach nawet do śmierci. Alergia obniża wydolność zawodową i wpływa negatywnie na wydolność edukacyjną. 
Te specyficzne potrzeby konsumentów powodują wzrost zapotrzebowania na produkty, w których całkowicie wyeliminowano alergeny, powodujące dolegliwości zdrowotne. Badania nauk medycznych wskazują że zarówno żywność ekologiczna jak i funkcjonalna może zapobiegać lub łagodzić skutki alergii pokarmowej. Problem alergii jest niezwykle ważny we współczesnym społeczeństwie nie tylko z punktu widzenia medycznego, ale również ekonomicznego i społecznego. Wydaje się, że poruszana problematyka jest uzasadniona $\mathrm{z}$ powodu potencjalnych korzyści zarówno dla konsumentów, zwłaszcza dzieci, jak i dla producentów.

Celem artykułu jest próba odpowiedzi na pytanie, czy i w jaki sposób dolegliwości alergiczne mogą wpływać na rozwój rynku żywności funkcjonalnej i ekologicznej oraz jakie wymagania powinny być spełnione na rynku żywności, aby zapewnić bezpieczeństwo i komfort konsumentowi-alergikowi? Rozpatrywano czy żywność ekologiczna i żywność funkcjonalna może być sposobem zapobiegania lub zmniejszania skutków alergii. Ponadto rozważano czy alergicy stanowią segment konsumentów, który warto wziać pod uwagę zarówno w segmentacji rynku jak i przy projektowaniu działań marketingowych. Dla zrealizowania celu wykorzystano metodę analizy i krytyki źródeł.

\section{Istota i przyczyny alergii}

Termin ,alergia” został wprowadzony przez austriackiego lekarza Clemensa von Pirgeta w 1906r. Jej etymologii należy się doszukiwać w języku greckim, gdzie allos oznacza inny a ergos - reakcję. Alergię określa się jako zdolność organizmu do specyficznego i anormalnego reagowania na obcy bodziec. Jest to reakcja obronna, stanowiąca odpowiedź organizmu na przeciwciała (zwane alergenami), która może doprowadzić do zaburzeń funkcjonowania organizmu $\mathrm{w}$ obronie przed ciałami obcymi i powstania chorób alergicznych i immunologicznych ${ }^{1}$. Reakcje alergiczne mogą mieć różną skalę $i$ konsekwencje. Najczęściej są to objawy chorobowe górnych dróg oddechowych (trudności W oddychaniu, obrzęk języka, gardła), objawy ze strony przewodu pokarmowego (bóle brzucha, wymioty, biegunki, zaparcia, wzdęcia, spadki wagi, a u dzieci niedożywienie), zmiany skórne (obrzęk oczu lub twarzy, wysypki skórne, obrzęk, świąd), a w cięższych przypadkach wstrząs anafilaktyczny, który może prowadzić nawet do śmierci.

Jedną z odmian alergii jest alergia pokarmowa. Jest definiowana jako nieprawidłowe i niepożądane reakcje organizmu na spożyty składnik pokarmu po spożyciu pokarmów, u podłoża których leżą mechanizmy immunologiczne ${ }^{2}$. Rozwija się wskutek defektu doustnej tolerancji, co jest wynikiem zaburzenia prawidłowej odpowiedzi immunologicznej na białka pokarmowe ${ }^{3}$. Należy odróżnić ją od nietolerancji pokarmowej u podłoża której leżą mechanizmy nieimmunologiczne tj. reakcje toksyczne, reakcje metaboliczno-biochemiczne czy farmakologiczne ${ }^{4}$. W 1995r. grupa ekspertów Food and Agriculture Organization określiła spis pokarmów najczęściej

\footnotetext{
${ }^{1}$ M.Krełowska-Kułas: Alergie pokarmowe, „Zeszyty Naukowe Akademii Ekonomicznej w Krakowie”, 2004, nr 705, s.93.

${ }^{2}$ M.Kaczmarski, E.Matuszewska: Diagnostyka alergii i nietolerancji pokarmowej u dzieci, „Alergia Astma Immunologia", 2000, nr 5(2), s.77.

${ }^{3}$ K. Wąsowska-Królikowska: Alergia pokarmowa, „Przegląd Alergologiczny”, 2004, 1-2, s.49.

${ }^{4}$ M.Kaczmarski, E.Matuszewska: op.cit, s.77.
} 
wywołujących alergie, który został potwierdzony przez Codex Alimentarius Commission i zyskał miano "wielkiej ósemki". Ponad 160 innych rodzajów żywności i dodatków znacznie rzadziej wpływa na pojawienie się objawów alergicznych ${ }^{5}$. Identyfikuje się zaledwie kilka alergenów, które są odpowiedzialne za większość alergii. Do nich należy: mleko krowie, jajka, orzechy, soja, pszenica, ryby i owoce morza. Nasilenie alergii pokarmowych oraz częstość ich występowania obecnie wzrasta. Szacuje się, że 220-250 milionów ludzi na całym świecie może mieć alergię pokarmową ${ }^{6}$. Wzrasta liczba dzieci posiadająca tę dolegliwość (wykres 1). Mieszkańcy Europy są głównie uczuleni na takie składniki pokarmowe jak mleko, jaja i orzechy ${ }^{7}$. Badania Wąsowskiej-Królikowskiej określają częstość występowania alergii pokarmowej na 6-8\% w 1. r.ż. i 1-2\% u dorosłych. Szczególnie niepokojący jest fakt, że w ostatnim okresie stwierdzono wzrost częstotliwości alergii pokarmowej, szczególnie u niemowląt, nawet wyłącznie karmionych piersią̨ ${ }^{8}$. Szacuje się, że 1/3 dzieci w Europie Zachodniej, Australii i USA jest uczulonych na orzeszki ziemne. Tego typu alergie również zaczynają być coraz bardziej powszechne w Azji i Afryce.

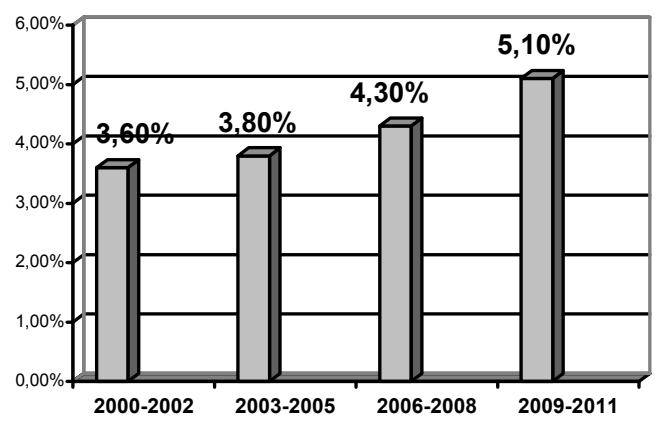

Wykres 1. Procentowy udział dzieci z alergią pokarmową w USA w latach 2000-2011 Źródło: Centers for Disease Control and Prevention, American Academy of Pediatrics za: http://www.allergyreliefexpert.com/food-allergy-statistics/ (25.11.2016).

Przyczyn alergii upatruje się w trzech grupach czynników. Są to czynniki genetyczne, czynniki środowiskowe i prowadzony styl życia. Istotne znaczenie mają czynniki środowiskowe, związane z zanieczyszczeniem wody, powietrza i żywności oraz zanieczyszczeniami znajdującymi się w domu i otoczeniu (kurz, chemia domowa, kosmetyki, sierść zwierząt). Należy zwrócić uwagę, że nadmierna higiena i sterylność sprzyja występowaniu alergii. Duże znaczenie też ma leczenie antybiotykami w

\footnotetext{
5 B.Wróblewska: Wielka ósemka alergenów pokarmowych, „Alergia”, 2002, $\mathrm{nr} \quad 4 / 15$, w: http://www.alergia.org.pl/lek.arch1/archiwum/02 04/pdf/wielka.pdf., data dostepu 20.06.2016.

${ }^{6}$ R.Pawankar, G.W. Canonica, S.T. Holgate, R.F. Lockey: Biała Księga Alergii, Światowej Organizacji Alergii 2011-2012, World Allergy Organization, 2011, s.4, w: https://www2.pta.med.pl/uploads/files/pl/strony/strefaczlonkowska/biala-ksiega-alergii/biala_ksiega_alergii.pdf, data dostępu: 27.06.2016.

${ }^{7}$ I.Traczyk, R.Wierzejska, M.Jarosz: Najczęściej spotykane alergeny pokarmowe, w: Alergie pokarmowe Porady lekarzy i dietetyków, pod red. M.Jarosz, J.Dzieniszewski, PZWL, Warszawa 2004, s.40.

${ }^{8} \mathrm{~K}$. Wąsowska-Królikowska: op.cit, s.49.
} 
pierwszych dwóch latach życia. Badania Lacka dodatkowo zwracają uwage na kulturowe i behawioralne uwarunkowania związane z częstotliwością, nasileniem i rodzajami objawów alergicznych u pacjentów ${ }^{9}$. Alergia pokarmowa ma poważne skutki dla codziennego życia człowieka, ponieważ jej objawy występują nie tylko w przewodzie pokarmowym, ale także mogą mieć wpływ na inne układy narządów ${ }^{10}$. Badania TNS OBOP z 2010r. pokazały, że około $30 \%$ polskich gospodarstw domowych boryka się ze schorzeniami na tle alergicznym ( $4 \% \mathrm{z}$ alergia pokarmowa). W szczególności dotykają one kobiet, które stanowią $67 \%$ wszystkich alergików. Dużą grupę (38\%) stanowią ludzie młodzi w wieku 15-29 lat. Trzy czwarte osób cierpiących na alergię to mieszkańcy miast. W Warszawie prawie co trzecie dziecko zmaga się z jej objawami ${ }^{11}$. Badania projektu „Epidemiologia Chorób Alergicznych w Polsce” rozpoczęte w 2008 r. wskazują jeszcze większą grupę posiadającą dodatnie testy na powszechnie występujące alergeny, a mianowicie $40 \%$ Alergię pokarmową posiada $13 \%$ dzieci w wieku 6-7 lat, $11 \%$ dzieci w wieku 13-14 lat i 5\% dorosłych. Problem alergii dotyczy szczególnie dużych miast ${ }^{12}$.

\section{Konsument-alergik a żywność funkcjonalna}

Na rynku pojawia się coraz większa liczba produktów adresowanych do konsumentów o prozdrowotnym stylu życia. Producenci projektują produkty, które są kierowane do ludzi z różnymi dolegliwościami zdrowotnymi. Do podstawowych rodzajów żywności, którą konsumenci określają jako tzw. „zdrową żywność” należy zaliczyć żywność funkcjonalna.

Rynek żywności funkcjonalnej rozwija się dynamicznie na całym świecie. Żywność funkcjonalna, jest to kategoria żywności o podwyższonej jakości zdrowotnej, gdzie naukowo udowodniono jej korzystny wpływ na jedną lub więcej funkcji organizmu ponad efekt odżywczy ${ }^{13}$. Ta definicja powstała w 1999r. w ramach programu Functional Food Science in Europe. Do niej należy zaliczyć żywność wzbogaconą w prozdrowotne dodatki witaminowe i substancje mineralne, błonnik pokarmowy, stanole i tosterole, kwasy thuszczowe omega-3, polifenole, flawonoidy, kwas $\gamma$-aminomasłowy, peptydy; żywność posiadającą probiotyki i prebiotyki; żywność obniżającą poziom cholesterolu, żywność zawierającą fitoestrogeny oraz są to produkty z mniejszą zawartością cukru, thuszczu, soli, pozbawione glutenu, soi lub laktozy oraz innych alergenów ${ }^{14}$.

Idea żywności funkcjonalnej powstała Japonii, gdzie dokładnie została ona zdefiniowana jako żywność ze specjalnymi żywieniowymi deklaracjami FHC (Food

\footnotetext{
${ }^{9}$ G. Lack: Update on risk factors for food allergy, "Journal Allergy Clinical Immunology”, 2012, nr 129, s. 1187-1197.

${ }^{10}$ J.S. Alm, J.Swartz, B. Björkstén, L. Engstrand, J. Engström, I. Kühn, G. Lilja, R. Möllby, E. Norin, G. Pershagen, C. Reinders, K. Wreiber, A. Scheynius: An anthroposophic lifestyle and intestinal microflora in infancy, ,Pediatric Allergy Immunology”, 2002, nr 13(6), s. 403.

${ }_{11}$ Alergia przypadtość XXI wieku, Dziennik.pl. z dnia 03.06.2014, data dostępu: 29.06.2016.

12 Warszawski Uniwersytet Medyczny, Epidemiologia Chorób Alergicznych w Polsce, 2008, w: http://ecap.pl/material.html, data dostępu: 29.06.2016.

${ }_{13}$ A.Filipiak-Florkiewicz, A. Florkiewicz, K. Topolska, A. Cabała: Żywność funkcjonalna (prozdrowotna) w opinii klientów specjalistycznych sklepów z żywnościa, „Bromatologia i Chemia Toksykologiczna”, 2015, nr 43(2), s. 166.

${ }^{14}$ por. A.Filipiak-Florkiewicz, A. Florkiewicz, K. Topolska, A. Cabała: op.cit., s.167.
} 
with Health Claims). Obejmuje ona dwie grupy: żywność zawierającą funkcjonalne składniki odżywcze tj. 12 witamin i 5 substancji mineralnych oraz żywność o określonym przeznaczeniu zdrowotnym, wpływająca dodatnio na stan fizjologiczny organizmu ludzkiego. $\mathrm{W}$ ostatnim przypadku konieczne jest badanie jej bezpieczeństwa $\mathrm{i}$ pozytywnego oddziaływania na zdrowie, które musi zostać zatwierdzone przez ministra zdrowia i opieki ${ }^{15}$. Biorąc pod uwagę przedmiot badań wydaje się użyteczny podział żywności funkcjonalnej na cztery grupy: żywność, w której zwiększono dostępność prozdrowotnych składników; naturalną żywność bogatą w składniki prozdrowotne; żywność, do której dodano składnik lub składniki prozdrowotne; żywność, z której usunięto składniki antyżywieniowe ${ }^{16}$.

Żywność funkcjonalna zyskuje coraz większą popularność (wykres 2 i wykres 3). Największy rynek jest nie tylko w Stanach Zjednoczonych i Japonii, ale również w Chinach i Europie (wykres 4). Światowy rynek żywności funkcjonalnej w 2013 roku osiągnął przychody w wysokości 168 miliardów dolarów, ze średnią roczną stopą wzrostu na poziomie około $8,5 \%$. Przewiduje się, że światowy rynek żywności funkcjonalnej przekroczy $2020 \mathrm{r}$. wartość 305,4 mld dolarów ${ }^{17}$. Szacuje się, że około $20 \%$ produktów spożywczych na rynku europejskim może stanowić żywność funkcjonalna ${ }^{18}$. Przyczynia się do tego wzrost świadomości konsumentów, co do związków pomiędzy zdrowiem a stylem życia, a szczególnie sposobem odżywiania.

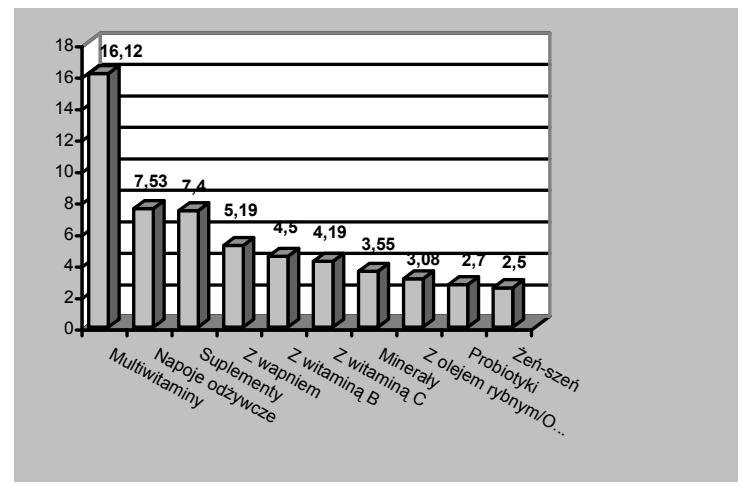

Wykres 2. Wartość globalnej sprzedaży żywności funkcjonalnej według typu produktu w 2011 roku (w bilionach dolarów)

Źródło: Euromonitor, Nutraceuticals World, 2011 za:

https://www.statista.com/statistics/253124/global-functional-food-sales-by-product-type/ data dostępu: 25.11.2016.

\footnotetext{
${ }^{15}$ K.Krygier, A.Florowska: Żywność funkcjonalna obecnie $i$ w przyszłości, „Przemysł Spożywczy”, 2008, nr 62(5), s.4.

${ }^{16}$ W. Kudełka: Innowacyjny segment żywności wspierajacej zdrowie człowieka, w: Nierówności społeczne a wzrost gospodarczy. Modernizacja dla spójności społeczno-ekonomicznej, 2011, nr 18, s. 292-293.

${ }^{17}$ PRNewswire: Global Functional Food and Nutraceuticals Market 2014-2020: Benefits, Origin \& Ingredients - Analysis of the \$168 Billion Industry, w:

http://www.researchandmarkets.com/research/33gvv3/global functional, data dostępu: 29.06.2016

${ }^{18}$ T. Rokicki: Czy mięso może być żywnościa funkcjonalnq?, „Gospodarka Mięsna”, 2007, nr 7, s. 21.
} 
Żywność funkcjonalna odgrywa ważną rolę $\mathrm{w}$ łagodzeniu skutków alergii. W badaniach Yao $\mathrm{i}$ in. wykazano, że zastosowanie probiotyków pomaga $\mathrm{w}$ łagodzeniu objawów alergii ${ }^{19}$. Badania Elazab i in. pokazują, że u kobiet przyjmujących probiotyki w czasie ciąży zauważono mniejsze ryzyko zachorowania na alergię ich dziecka ${ }^{20}$. Skuteczne unikanie alergenów prowadzi do złagodzenia objawów u chorych na alergie ${ }^{21}$. W krajach wysokorozwiniętych powstała cała gama specjalnie zaprojektowanych produktów, gdzie wyeliminowano 8 najczęstszych alergenów.

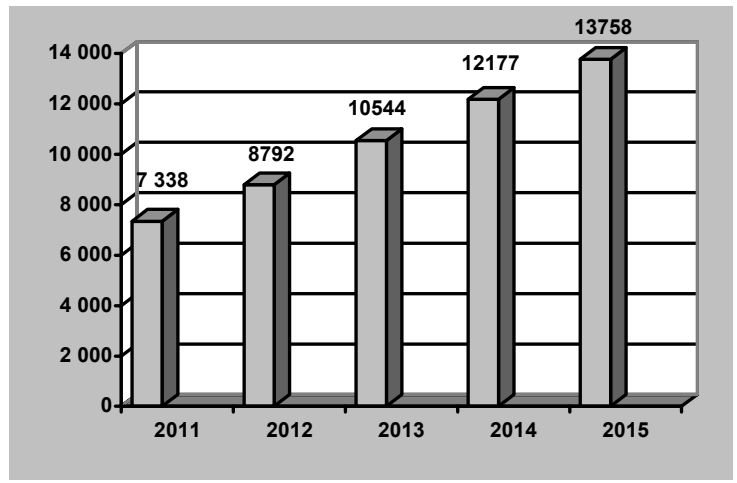

Wykres 3. Wartość sprzedaży detalicznej produktów bezglutenowych w USA w latach 2011-2015 (w mln dolarów)

Źródło: Specialty Food Association,SPINS, Nielsen, Mintel za:

https:/www.statista.com/statistics/301621/us-retail-dollar-sales-of-gluten-free-products/, data dostępu: 25.11.2016.

W medycynie rekomenduje się zwłaszcza w przypadku dzieci i ich żywienia diety eliminacyjne i rotacyjne. Dieta eliminacyjna polega na rezygnacji z pokarmów negatywnie wpływających na organizm i tym samym na wyciszeniu reakcji immunologicznych. Jest to jeden z najskuteczniejszych sposobów leczenia objawów chorobowych rozwijających się po spożyciu alergenu. Ma najlepszy stosunek skuteczności do kosztów i powikłań. Istnieje także możliwość przywrócenia tolerancji na pokarm, który wcześniej wywoływał reakcję alergiczną i całkowity powrót do zdrowia, szczególnie ma to znaczenie u dzieci. Ten rodzaj diety niesie ryzyko niedożywienia i niedoborów pokarmowych. W przypadku uczulenia na kilka bądź kilkanaście produktów spożywczych zaleca się dietę rotacyjną polegającą na cyklicznym spożywaniu określonej grupy produktów lub produktu spożywczego w pierwszym dniu cyklu (trwającego od 4 do 6 dni), a następnie powstrzymywaniu się od jego spożywania aż do pierwszego dnia kolejnego cyklu. Jest ona trudniejsza w stosowaniu i wymaga konsultacji $\mathrm{z}$ dietetykiem $\mathrm{i}$ indywidualnego podejścia ze względu na reakcje

${ }^{19}$ T.C.Yao, C.J.Chang, Y.H.Hsu, J.L. Huang: Probiotics for allergic diseases: Realities and myths, "Pediatric Allergy Immunology, 2010, $\mathrm{nr}$ 21(6), s. 900-919.

${ }^{20}$ N.Elazab, A.Mendy, J.Gasana, E.R.Vieira, A.Quizon, E.Forno: Probiotic Administration in Early Life. Atopy, and Asthma: A Meta-analysis of Clinical Trials, "Pediatrics", 2013, nr 132 (3), s.666-676.

${ }^{21}$ R.Pawankar, G.W.Canonica, S.T. Holgate, R.F. Lockey: op.cit. 
organizmu. ${ }^{22}$ Te same badania pokazały, że $86 \%$ rodziców stosowało dietę eliminacyjna, ale tylko niespełna połowa ankietowanych zastępowała produkty wyeliminowane $\mathrm{z}$ diety dziecka substytutami ${ }^{23}$.

Istnieje niebezpieczeństwo, że konsumenci mogą upatrywać w żywności funkcjonalnej rozwiązania swoich problemów zdrowotnych. Brak jest świadomości, że żywność funkcjonalna, przyjmowana regularnie i w połączeniu ze zbilansowaną dietą, aktywnością fizyczną i innymi zachowaniami prozdrowotnymi jak zapewnienie organizmowi snu, odpoczynku oraz unikanie stresu, alkoholu itp. daje efekt prozdrowotny.

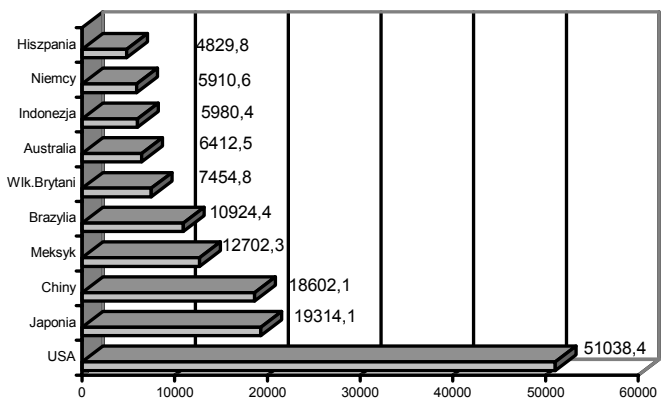

Wykres 4. Wartość rynku żywności funkcjonalnej w 2012 roku (w milionach dolarów)

Źródło: Euromonitor, 2012 za: http://www5.agr.gc.ca/eng/industry-markets-and-trade/statisticsand-market-information/agriculture-and-food-market-information-by-region/united-states-andmexico/market-intelligence/fortified-functional-foods-and-beverages-inmexico/?id=1410083148553\&wbdisable=true, data dostępu: 25.11.2016.

Bogata oferta żywności funkcjonalnej może być myląca dla przeciętnego konsumenta a nawet przytłaczająca. Efekty działań marketingowych są trudne do odróżnienia od naukowo potwierdzonych dowodów dotyczących właściwości tych produktów $^{24}$.

\section{Alergicy jako jeden $z$ podstawowych segmentów rynku żywności ekologicznej}

Żywność ekologiczna jest to żywność wytworzona w rolnictwie ekologicznym oraz odpowiednio oznaczona na rynku. Obecnie rynek żywności ekologicznej należy do najbardziej dynamicznie rozwijających się sektorów przemysłu spożywczego, ale nadal jest on niewielki. W 2013r. na świecie uprawy żywności ekologicznej objęły obszar ponad 43 mln hektarów w 170 krajach. Stanowi to jedynie 1\% całkowitej powierzchni upraw. Wydatki konsumentów w UE na żywność ekologiczną w 2013r. wyniosły 22

22 P.Kalinowski, K.Mirosław: Wiedza rodziców na temat alergii pokarmowej wystęujacej $u$ ich dzieci, „Medycyna Ogólna i Nauki o Zdrowiu”, 2014, nr 20(1), s.90.

23 op.cit.: s.89-90.

${ }^{24}$ K.Krygier, A.Florowska: op.cit., s.4. 
miliardów $€$, co spowodowało ich wzrost o prawie $6 \% \mathrm{w}$ porównaniu do ubiegłego roku. Największą sprzedaż wygenerowano we Francji (4,4 mld €), Wielkiej Brytanii (2,1 mld $€)$ i we Włoszech ( 2 mld $€$ ), ale największa liczba producentów ekologicznych występuje we Włoszech, w Hiszpanii i w Polsce ${ }^{25}$. Nie tylko zainteresowanie konsumentów, ale również działania mediów, polityka rolna, włączenie sklepów wielkopowierzchniowych do sprzedaży wpływa na wzrost rynku żywności ekologicznej. Hartman Group zidentyfikował determinanty, które nakłaniają konsumentów do pierwszych zakupów. Są to: ciąża, warunki zdrowotne i wpływ społeczny ${ }^{26}$. Konsumenci kupują żywność ekologiczna, ponieważ uważają ją za bardziej bezpieczną od żywności konwencjonalnej ${ }^{27}$. Odnosi się to do braku toksyn lub szkodliwych substancji chemicznych, takich jak nawozy czy pestycydy ${ }^{28}$. Niektórzy konsumenci są przekonani, że żywność ekologiczna jest bardziej pożywna niż konwencjonalna i widzą w jej konsumpcji wymierne korzyści dla siebie.

Polscy konsumenci oczekują od produktów walorów odżywczych i zdrowotnych oraz poszukują produktów pozbawionych konserwantów i o odpowiednim składzie ${ }^{29}$. Na podstawie wyników badań można stwierdzić, że w odczuciu konsumentów żywność bezpieczna dla zdrowia to: żywność świeża, bez konserwantów i dodatków oraz żywność z rolnictwa ekologicznego. Tylko $1 \%$ konsumentów uważała, że każda żywność dostępna na rynku jest bezpieczna ${ }^{30}$.

Wyniki badań W. Łuczki-Bakuły pokazały, że żywność ekologiczna jest postrzegana jako żywność charakteryzująca się przede wszystkim prozdrowotnymi walorami. Łączy się to z motywami jej nabywania, gdzie dominuje troska o zdrowie ${ }^{31}$. Oprócz troski o zdrowie stosowana dieta stanowi podstawowy powód jej zakupu ${ }^{32}$. Według ostatniej analizy GfK Polonia, aż 67\% konsumentów uważa, że naturalne walory żywności są ważniejsze niż prozdrowotne wartości dodane do poszczególnych wyrobów 33 . Konsumenci doceniają $\mathrm{w}$ większym stopniu produkty, które są uprawiane metodami tradycyjnymi, w których wyłączono metody przyspieszenia wzrostu roślin niż produkty

25 European Parliament: Organic food: Helping EU consumers make an informed choice, 2015, w: http://www.europarl.europa.eu/RegData/etudes/BRIE/2015/557009/EPRS_BRI(2015)557009_EN.pdf, data dostępu: 24.10.2016.

${ }^{26}$ Hartman Group: Academics-Review_Organic-Marketing-Report, 2013, w: http://academicsreview.org/wpcontent/uploads/2014/04/Academics-Review_Organic-Marketing-Report1.pdf., data dostępu: 05.01.2016.

${ }^{27}$ S.N.B.B.Ahmad: Organic food: A study on demographic characteristics and factors influencing purchase intentions among consumers in Klang Valley, Malaysia,."International Journal of Business and Management", 2010, nr 5(2), s.105-118.

${ }^{28}$ S.Baker, K.E. Thompson, J. Engelken: Mapping the values driving organic food choice: Germany vs the UK, "European Journal of Marketing", 2004, nr 38(8), s.995-1012.

29 M.Angowski, M.Lipowski: Uwarunkowania wyboru produktów żywnościowych $i$ miejsc ich zakupu, „Marketing i Rynek”, 2014, nr 6 (CD), s.2-16.

${ }^{30}$ A.Kabacińska, A.Rybowska, E.Babicz-Zielińska: Rodzaje żywności zaliczanej przez konsumentów do tzw zdrowej, w: Konsument żywności i jego zachowania rynkowe $w$ warunkach członkostwa $w$ UE pod red. K.Gutkowska, L.Narojek, Wyd. SGGW, Warszawa 2005, s. 255-258.

${ }^{31}$ W.Łuczka-Bakuła: Rynek żywności ekologicznej. Wyznaczniki i uwarunkowania rozwoju, PWE, Warszawa 2007, s.128-130.

${ }^{32}$ B.Sojkin, J.Witczak: Konsument żywności ekologicznej w dużym mieście, w: Badanie rozwoju rynków produktów rolnictwa ekologicznego i żywności ekologicznej $w$ Polsce pod red. A.Graczyk, K.MazurekK.Łopacińskiej, Wyd. Uniwersytetu Ekonomicznego we Wrocławiu, Wrocław 2009, s.158.

${ }^{33} \mathrm{http}: / /$ www.biznes.newseria.pl/news/wartosc_rynku_zywnosci,p863804847 (wpis: 18.10.2016) data dostępu: 23.10.2016 
wytworzone z wykorzystaniem nowoczesnej technologii, nawozów sztucznych oraz wzbogacone o witaminy, minerały i inne prozdrowotne dodatki. W Polsce można zauważyć dość dynamiczny rozwój rynku żywności ekologicznej, zarówno ze strony popytu jak i podaży. Pomimo, że liczba gospodarstw ekologicznych na koniec 2015 roku zmniejszyła się w stosunku do roku poprzedniego (z 25427 do 23015), eksperci tego rynku prognozują jego dynamiczny rozwój oraz wzrost wydatków konsumentów na tę kategorię żywności. Duża część wydatków nie jest ewidencjonowana, ponieważ polscy konsumenci kupują na targowiskach, bazarach oraz z tzw. sprawdzonego źródła. Przewiduje się, że popyt będzie się zwiększał ze względu na wzrost zamożności polskiego społeczeństwa, na poszukiwanie nowych rozwiązań żywieniowych, a także na wzrastającą świadomość ekologiczną i prozdrowotną Polaków ${ }^{34}$.

Badania Alm i in. wykazały, że żywność ekologiczna ma pozytywny wpływ na łagodzenie alergii ${ }^{35}$. Konsumpcja żywności organicznej zawierającej laktobakterie i pozbawionej antybiotyków, szczepionek została powiązana ze zmniejszonym występowaniem alergii. Badania Journal of Agricultural i Chemii Żywności potwierdziły, że ekologiczne jagody i kukurydza zawierały o 58\% więcej przeciwutleniaczy, które pomagają zapobiegać chorobom układu sercowo-naczyniowego oraz posiadały o $52 \%$ wyższy poziom witaminy $\mathrm{C}$ niż odpowiedniki uprawiane tradycyjnie ${ }^{36}$. Według badań Organic Food Labels z 2014 roku konsumenci odczytują produkty oznaczone ,organic" jako produkty pozbawione pestycydów (81\%) i antybiotyków $(66 \%)^{37}$.

Barierą regularnych zakupów organicznych (podobnie jest w przypadku żywności funkcjonalnej) są wysokie ceny i brak dostępności. Badania Gutkowskiej i Ozimek wskazują na podstawowe przyczyny nienabywania żywności ekologicznej. Sa to ograniczenia związane $z$ jej dostępnością, ograniczania finansowe, a także brak wiedzy konsumentów, aby ją odróżnić na rynku oraz brak zaufania do certyfikowanych produktów $^{38}$.

\section{Wnioski i konkluzje}

Obecnie można zaobserwować upowszechnianie zdrowego stylu życia oraz traktowanie przez konsumentów żywności jako lekarstwa, co oznacza, że żywność jest stosowana w celu zmniejszenia przyjmowania leków, których spożywanie nie jest obojętne dla organizmu. Powoduje to rozwój rynku żywności funkcjonalnej i ekologicznej, który jest ściśle związany ze świadomością konsumentów oraz ich edukacją zdrowotną, a szczególnie żywieniową, w którą należy włączyć dużą grupę interesariuszy: media, naukowców, technologów żywności, przedsiębiorstwa i lekarzy.

34 B.Pilarczyk, R. Nestorowicz: Marketing ekologicznych produktów żywnościowych, Wolters Kluwer, Warszawa 2010, s.241.

${ }_{36}^{35}$ J.S. Alm, J. Swartz i in.: op.cit., s. 404.

${ }_{36}$ Badania Journal of Agricultural i Chemii Żywności, 2003 w: http://www.eatingwell.com/food_news_origins/green_sustainable/organic_or_not_is_organic_produce_healthi er_than_conventional, data dostępu 26.06.2016.

Consumer Reports National Research Center, Organic Food Labels Survey, 2014, w: http://www.greenerchoices.org/pdf/CR2014OrganicFoodLabelsSurvey.pdf, data dostępu: 26.06.2016.

38 K.Gutkowska, I.Ozimek: Wybrane aspekty zachowań konsumentów na rynku żywności - kryteria zróżnicowania, Wydawnictwo SGWW, Warszawa 2005, s.210-211. 
Postęp cywilizacyjny i zanieczyszczenia środowiska sprawiają wzrost liczby osób, zwłaszcza dzieci, które cierpią z powodu licznych alergii, zwłaszcza pokarmowych. Nowe potrzeby konsumentów związane $\mathrm{z}$ dolegliwościami alergicznymi posiadają liczne implikacje dla działań producentów. Projektowanie specjalnych, bezpiecznych produktów, zapewnienie ich dostępności i czytelnego oznakowania, odpowiednia edukacja konsumentów, a także zaoferowanie bezpiecznych substytutów to podstawowe wyzwania dla firm.

W wielu krajach świata brakuje odpowiednich wytycznych i przepisów legislacyjnych dotyczących oznakowania produktów spożywczych. Z punktu widzenia medycznego istotne jest zwiększenie dostępności procesów diagnostycznych i leczniczych. Należy zaznaczyć, że wzrasta świadomość konsumentów, którzy mają coraz większą wiedzę na temat wpływu żywności na zdrowie. Są bardziej wymagający, identyfikują skład żywności, poszukują informacji na temat składników, cech, korzyści oraz sposobu oddziaływania poszczególnych składników na organizm, sposobu produkcji oraz miejsc zakupu produktów „zdrowych” w celu zapewnienia bezpieczeństwa sobie i swoim bliskim ${ }^{39}$.

Na rynku można zauważyć dość ograniczoną ofertę produktową dla alergików, która jest dodatkowo trudno dostepna. W sklepach tradycyjnych produkty nie zawsze posiadaja jasne i dokładne informacje, co powoduje, że taki konsument nawet podczas rutynowych zakupów musi poświęcić dużo czasu na analizę etykiet (pod warunkiem, że ma wiedze jak czytać etykiety). Zazwyczaj jest tylko informacja, że produkt może zawierać np. orzechy, jaja, soję. W sklepach specjalistycznych z tzw. „zdrową” żywnością można zakupić produkty, gdzie wyeliminowano alergeny, ale są to produkty posiadające ceny o wiele wyższe niż konwencjonalne ich odpowiedniki oraz takie punkty sprzedaży są terytorialnie rozproszone. Sprawia to, że grupa konsumentów posiadająca problemy zdrowotne znajduje się $\mathrm{W}$ trudnej sytuacji poszukując odpowiednich produktów, które nie zagrażałaby zdrowiu rodziny. Na polskim rynku istnieje nisza rynkowa związana $\mathrm{z}$ produktami dla alergików. Biorąc pod uwage prognozy, że liczba alergików będzie wyższa niż nie-alegików, to w przyszłości $\mathrm{z}$ pewnością pojawią się sklepy, restauracje oraz usługi taxi, sprzątania dla alergików.

Wiedza konsumenta jest ważnym elementem determinującym jego orientację prozdrowotną. Szczególnie wiedza rodziców na temat alergii jest bardzo istotna, gdyż to oni są odpowiedzialni za zakup odpowiednich produktów oraz stosowanie diet u dzieci, zwłaszcza tych najmłodszych, które nie są jeszcze w stanie zrozumieć istoty swojego schorzenia i samodzielnie eliminować szkodliwe produkty. Obecnie media tradycyjne i elektroniczne odgrywają ogromną rolę w edukacji społeczeństwa i kształtowaniu opinii, $\mathrm{w}$ tym dotyczących zachowań zdrowotnych ${ }^{40}$. Wiedza rodziców na temat alergii i jej profilaktyki jest niska i cząstkowa. Niewiele ponad połowa badanych przekazuje informacje na temat alergii pokarmowej swoim dzieciom, ale głównymi źródłami wiedzy rodziców na ten temat są znajomi i rodzina oraz Internet. Większość rodziców stosuje się do zaleceń dotyczących wprowadzania diety, ale usuwając produkty

\footnotetext{
${ }^{39}$ L.Witek, K.Szalonka: Wpływ zachowań nabywców na rozwój nowych kanałów dystrybucji „zdrowej”, żywności w: Handel we wspótczesnej gospodarce. Nowe wyzwania, pod red. M. Sławińskiej, Uniwersytet Ekonomiczny w Poznaniu, Poznań 2016, s.287.

${ }^{40}$ E.Szymczuk, J.Zajchowska, A.Dominik, M.Makara-Studzińska, A.Zwolak, J.Daniluk: Media jako źródło wiedzy o zdrowiu, „Medycyna Ogólna i Nauki o Zdrowiu”, 2011, nr 17(4), s. 165-168.
} 
zawierające uczulający składnik, w większości nie zastępują ich innymi o podobnej wartości odżywczej ${ }^{41}$.

$\mathrm{Z}$ punktu widzenia medycznego problem alergii jest dobrze rozpoznany, ale z punktu widzenia ekonomicznego brak jest badań zachowań rynkowych alergików. Ten artykuł stanowi wprowadzenie do kolejnych rozważań i badań empirycznych, które zostaną podjęte w przyszłości przez autorki artykułu. Badania nad zachowaniami konsumentówalergików stwarzają możliwość pozyskania informacji o zachowaniach tej specyficznej grupy konsumentów, ich uwarunkowaniach i mechanizmach oraz stanowią istotną pomoc w segmentacji rynku, dostarczając wielu informacji i stwarzając podstawy w zakresie grup potrzeb i produktów.

Artykuł dostarcza podmiotom na rynku produktów prozdrowotnych przydatnych informacji. Wskazuje, że alergicy jest to segment konsumentów o specyficznych potrzebach, który warto wziąć pod uwagę. Wyniki dotyczące determinant zachowań konsumentów na rynku żywności ekologicznej i funkcjonalnej implikują wskazówki dla strategii produktu i komunikacji marketingowej. Uczestnicy rynku m.in. przedsiębiorstwa wytwarzające produkty prozdrowotne, ich dystrybutorzy oraz organizacje społeczne powinni zadbać o przekazanie wiedzy konsumentom na temat oznakowań produktów i ich cech oraz wyjaśnienie warunków prozdrowotnego wpływu żywności funkcjonalnej.

\section{Literatura}

Ahmad S.N.B.B.: Organic food: A study on demographic characteristics and factors influencing purchase intentions among consumers in Klang Valley, Malaysia, „International Journal of Business and Management”, 5(2)/2010, s.105-118.

Alergia przypadłość XXI wieku: ( 03.06.2014), Dziennik.pl., data dostępu: 29.06.2016.

Alm J.S., Swartz J., Björkstén B., Engstrand L., Engström J., Kühn I., Lilja G., Möllby R., Norin E., Pershagen G., Reinders C., Wreiber K., Scheynius A.: An anthroposophic lifestyle and intestinal microflora in infancy, ,, Pediatric Allergy and Immunology, 13(6)/2002,s.402-411.

Angowski M., Lipowski M.: Uwarunkowania wyboru produktów żywnościowych i miejsc ich zakupu, „Marketing i Rynek”, nr 6 (CD)/ 2014, s.2-16.

Badania Journal of Agricultural i Chemii Żywności, 2003, w:

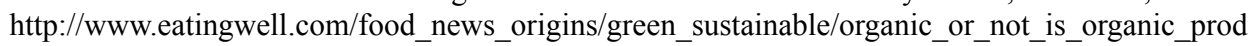
uce_healthier_than_conventional, data dostępu: 26.06.2016.

Baker S., Thompson K.E., Engelken J.: Mapping the values driving organic food choice: Germany vs the UK, "European Journal of Marketing", 38(8)/2004, s.995-1012.

Consumer Reports National Research Center: Organic Food Labels Survey, 2014, http://www.greenerchoices.org/pdf/CR2014OrganicFoodLabelsSurvey.pdf. data dostępu: 26.06.2016

Elazab N., Mendy A., Gasana J., Vieira R.E., Quizon A., Forno E.: Probiotic Administration in Early Life, Atopy, and Asthma: A Meta-analysis of Clinical Trials, "Pediatrics" 132 (3)/2013, s. 666-676.

European Parliament: Organic food: Helping EU consumers make an informed choice, 2015, w: http://www.europarl.europa.eu/RegData/etudes/BRIE/2015/557009/EPRS_BRI(2015)557009_EN. pdf, data dostępu: 24.10.2016.

${ }^{41}$ P.Kalinowski, K. Mirosław: Wiedza rodziców na temat alergii pokarmowej wystęujacej u ich dzieci, „Medycyna Ogólna i Nauki o Zdrowiu”, 2014, nr 20 (1), s. 88-91. 
Filipiak-Florkiewicz A., Florkiewicz A., Topolska K., Cabała A.: Żywność funkcjonalna (prozdrowotna) w opinii klientów specjalistycznych sklepów z żywnościq, „Bromatologia i Chemia Toksykologiczna", 43(2)/ 2015, s.166-175.

Gutkowska K., Ozimek I.: Wybrane aspekty zachowań konsumentów na rynku żywności - kryteria zróżnicowania, Wydawnictwo SGWW, Warszawa 2005.

Hartman Group: Academics-Review_Organic-Marketing-Report, 2013, w: http://academicsreview.org/wp-content/uploads/2014/04/Academics-Review_Organic-MarketingReport1.pdf., data dostepu: 05.01.2016.

Kabacińska A., Rybowska A., Babicz-Zielińska E.: Rodzaje żywności zaliczanej przez konsumentów do tzw. zdrowej, w: Konsument żywności i jego zachowania rynkowe $w$ warunkach czlonkostwa w UE, pod red. Gutkowska K., Narojek L., Wyd. SGGW, Warszawa 2005. Kaczmarski M., Matuszewska E.: Diagnostyka alergii $i$ nietolerancji pokarmowej $u$ dzieci, „Alergia. Astma. Immunologia”, 5(2)/ 2000, s.77-81.

Kalinowski P., Mirosław K.: Wiedza rodziców na temat alergii pokarmowej wystęujacej $u$ ich dzieci, „Medycyna Ogólna i Nauki o Zdrowiu”, 20(1)/ 2014, s.88-91.

M.Krełowska-Kułas: Alergie pokarmowe, „Zeszyty Naukowe Akademii Ekonomicznej w Krakowie", 705/2004, s.93-99.

Krygier K., Florowska A.: Żywność funkcjonalna obecnie i w przyszłości, „Przemysł Spożywczy”, 62(5)/ 2008, s.2-6.

Kudełka W.: Innowacyjny segment żywności wspierajacej zdrowie człowieka, w: Nierówności społeczne a wzrost gospodarczy. Modernizacja dla spójności społeczno-ekonomicznej, 18/2011, s. 290-302.

Lack G.: Update on risk factors for food allergy, "Journal Allergy Clinical Immunology", 129/2012, s. 1187-1197.

Lehrer S.B., Horner W.E., Reese G.: Why are Some Proteins Allergenic? Implication for Biotechnology, "Critical Reviews in Food Science and Nutrition", 36(6)/1996, s.553-564.

Łuczka-Bakuła W.: Rynek żywności ekologicznej. Wyznaczniki $i$ uwarunkowania rozwoju, PWE, Warszawa 2007.

Pawankar R., Canonica G.W., Holgate S.T., Lockey R.F.: Biała Księga Alergii, Światowej Organizacji Alergii 2011-2012, 2011W, World Allergy Organization, s.1-14, w: https://www2.pta.med.pl/uploads/files/pl/strony/strefa-czlonkowska/biala-ksiega-

alergii/biala_ksiega_alergii.pdf, data dostępu: 27.06.2016.

Pilarczyk B., Nestorowicz R.: Marketing ekologicznych produktów żywnościowych, Wolters Kluwer, Warszawa 2010.

PRNewswire: Global Functional Food and Nutraceuticals Market 2014-2020: Benefits, Origin \& Ingredients-Analysis of the $\$ 168$ Billion Industry, (18.02.2015), http://www.researchandmarkets.com/research/33gvv3/global_functional, data dostępu: 29.06.2016. Rokicki T.: Czy mięso może być żywnościa funkcjonalna?, „Gospodarka Mięsna”, 7/2007, s. 2022.

Sojkin B., Witczak J.: Konsument żywności ekologicznej w dużym mieście, w: Badanie rozwoju rynków produktów rolnictwa ekologicznego i żywności ekologicznej $w$ Polsce, pod red. Graczyka A., Mazurek-Łopacińskiej K. (red.), Wyd. Uniwersytetu Ekonomicznego we Wrocławiu, Wrocław 2009.

Szymczuk E., Zajchowska J., Dominik A., Makara-Studzińska M., Zwolak A., Daniluk J.: Media jako źródło wiedzy o zdrowiu", Medycyna Ogólna i Nauki o Zdrowiu”, 17(4)/ 2011, s.165-168.

Traczyk I., Wierzejska R., Jarosz M.: Najczęściej spotykane alergeny pokarmowe, w: Alergie pokarmowe. Porady lekarzy i dietetyków, pod red. Jarosz M., Dzieniszewski J., PZWL, Warszawa 2004.

Warszawski Uniwersytet Medyczny: Epidemiologia Chorób Alergicznych w Polsce, 2008, w: http://ecap.pl/material.html, data dostępu: 29.06.2016.

Wąsowska-Królikowska K.: Alergia pokarmowa, ”Przegląd Alergologiczny”, 1-2/(2004, s.49-51. 
Witek L., Szalonka K.: Wpływ zachowań nabywców na rozwój nowych kanałów dystrybucji „zdrowej” żywności, w: Handel we wspótczesnej gospodarce. Nowe wyzwania, pod red. M. Sławińskiej M., Uniwersytet Ekonomiczny w Poznaniu, Poznań 2016, s.283-294.

Wróblewska B.: Wielka ósemka alergenów pokarmowych, „Alergia”, 4(15)/2002, w: http://www.alergia.org.pl/lek.arch1/archiwum/02_04/pdf/wielka.pdf, data dostępu: 20.06.2016.

Yao T.C., Chang C.J., Hsu Y.H., Huang J.L.: Probiotics for allergic diseases: Realities and myths, "Pediatric Allergy Immunology", 21(6)/ 2010, s. 900-919.

\section{Summary}

The civilization progress in hygiene and environmental pollution have led to an increase of allergic diseases (especially among children), with makes that the number of allergy sufferers is large and is constantly growing. This is a troublesome disease that causes not only a decrease in quality of life, its impairment, and in extreme cases it may lead to death. Allergy reduces the professional capacity and affects negatively educational performance. The specific needs of consumers cause an increase in demand for organic products and functional food, especially products which completely eliminate allergens which cause discomfort. Research indicates that both organic and functional food can prevent or mitigate the effects of food allergy.

Key words: food dysfunctions, food allergy, functional foods, organic foods, consumer, health.

Informacja o autorach:

\section{dr Lucyna Witek}

Politechnika Rzeszowska,

Wydział Zarządzania, Katedra Marketingu,

ul. Powstańców Warszawy 8 ,

35-959 Rzeszów

e-mail: lgarbacz@prz.edu.pl

dr hab. Katarzyna Szalonka

Uniwersytet Wrocławski

Wydział Prawa, Administracji i Ekonomii, Instytut Nauk Ekonomicznych

ul. Uniwersytecka 22/26,

50-145 Wrocław

e-mail: katarzyna.szalonka@uwr.edu.pl 